It is not possible, in a brief review, to discuss detail in a book as extensive as this one and, in any event, the criticism of detail is best left to the teacher or the research worker who uses the book and advises students about it. Buti a word must be said in praise of the 62 figures, most of which are made up of several individual line drawings, among which are silhouettes of parasitic helminths which give their natural size, a useful feature which appears in other books, but not to the extent to which it is here employed. The production of the book must, also be praised; it is well printed, in clear type, in parallel columns on a large page and, unlike some very heavy text-books on this subject, it is delightfully light.

G. IAPAGE

\section{PLANNING FOR THE CHANGING WORLD POPULATION}

\section{Our Developing World}

By Prof. L. Dudley Stamp. Pp. 195. (London: Faber and Faber, Ltd., 1960.) 21s. net.

D ROF. DUDLEY STAMP gave the Patten Foundation Lectures at the University of Indiana in 1950. These lectures were expanded and published in 1952 by the Indiana University Press and the American Geographical Society under the title "Land for Tomorrow", and were revised for the English edition "Our Undeveloped World", published in 1953 .

Rapidly changing world populations, land-use values and food supply, urbanization, and new developments in farming, in mechanization of agriculture and in plant and animal genetics during the past seven or eight years have made further revision necessary, and "Our Developing World" now appears as a new book emphasizing the same fundamental point of view of the author on the ever-inereasing pressure of population on land resources and incorporating, where appropriate, much material from the two earlier books, but also bringing new thought to the problems of under-developed lands.

At the present rate of increase, world population will be doubled in less than forty years. This problem and its related one of planning land use are considered on the world-level, the national level with extremes of wealth in some countries and poverty in others, the regional level and local level. Farming is rapidly becoming a specialized industry. The pro. portion of population engaged in farming is decreasing almost all over the world, and while the movement is generally away from subsistence farming to commercial agriculture it must not be assumed that increasing industrialization and decreasing agriculture are necessarily the panacea for all ills associated with under-development.

Increasing urbanization is a pressing problem, and growth of cities cannot easily be limited. Efforts should be directed towards improving the urban environment as part of a correct land-use programme. The need for mapping the present distribution of population is as important as that for mapping the use of land, and a Commission has been set up by the International Geographical Union for the study of this problem. The geographical distribution of pests and diseases in man, animals and crops is another contributory study to population and land-use problems.
Prof. Dudley Stamp's conclusions are that world starvation is not just around the corner, that the population of the Farth could be increased to many times its present number without starvation providerl man-made barriers are broken down and food is produced efficiently by a comparatively small number. of specialist farmers. M. K. Milne

\section{CONTINUITY IN A SMALL PACIFIC ISLAND}

Social Change in Tikopia

Re-Study of a Polynesian Community after a (ieneration. By Raymond Firth. Pp. $360+8$ plates. (London: George Allen and Unwin, Ltd., 1959.) 45s. net.

$\mathrm{T}$ IKOPIA is an isolated speck of land seven miles in circumference with a population of fewer than 2,000 souls; it is one of the smallest of the small islands on the periphery of the British Solomon Islands Protectorate, of which entity it has been politically since 1898 a remote outlying fragment. The nearest land is another islet, Anuta, 70 miles to the north-east ; the nearest administrative officer of the Protectorate resides at Vanikoro in the Santa Cruz Group, 130 miles away ; it is 500 miles distant from the Solomon Islands proper.

This dot in the Pacific Ocean is inhabited by a community of Polynesians left behind during the great migrations that led the main branches of the race on to Samoa and Tonga, the Ellice and Cook Islands and Tahiti, to Hawaii in the north, New Zealand in the south and Easter Island in the far east of the Pacific. Cut off since those migrations from the centres of Polynesian life, the people of Tikopia and of the other islets in the Solomon Islands' "Polynesian Fringe" have continued to live in isolation as they had always lived; even in the first half of this century they were seldom visited more than about once a year by a Mission ship or a government officer. Before the Second World War, practically no Tikopians ever left their island (except perhaps for a temporary sojourn in Anuta) to return with new ideas from the outside world of other Pacific islands, for a paternal if distant Government wisely forbade recruiting-vessels to take them away to work elsewhere.

Tikopia was therefore the perfect subject for a detailed anthropological study; and in 1929 Prof. Raymond Firth concluded a long and solitary residence with this small, homogeneous and hitherto unchanged community; the principal findings of his study were published as a substantial volume in 1936 under the title "We, the Tikopia". After an interval of twenty-three years he decided to reinvestigate the Tikopians (on this occasion in the company of a colleague) partly "to throw some further light on the analysis of the dynamics of small-scale integral social systems", but more particularly to ascertain what had happened to these hitherto sheltered islanders in a period that had seen, owing largely to a world war, such drastic changes in other parts of the Pacific.

What did he find? The first and most obvious impression was the sad destruction wrought by a hurricane shortly before his return, with its resultant grave reduction of foodstuffs and threat of famine. He then found, as he pursued his investigations, that the War had left Tikopia alone since, luckily for its 